\title{
A heterodox structural Keynesian: honouring Augusto Graziani
}

\author{
Riccardo Bellofiore \\ University of Bergamo, Italy
}

Translated from the Italian by Antoine Godin

The article gives an appraisal of Augusto Graziani's thought as a heterodox structural Keynesian. Graziani has always challenged the basic assumptions of orthodox theory by rejecting the initial definition of the economic and social world as being populated by identical individuals, where consumers are sovereign, technology is exogenous and money is neutral. Since the 1970s, Graziani's efforts have aimed at rebuilding on solid foundations the line of inquiry that sees capitalism as a 'monetary economy of production'. Authors such as Schumpeter and Keynes, and before them Wicksell and Marx, were all key influences on Graziani's work. This theoretical attitude shaped Graziani's studies on the Italian economy within the European and the global landscapes. We are confronted here with an idea of state intervention where demand policies are not separated from supply-side policies, and are indeed embodied in a structural design to redefine the composition of production with great attention to the quality of labour. He reminds us that economic theory has to put at the heart of its discourse not the 'imperfections' of the market, but rather the 'normality' of power and conflict, not only between labour and capital, but also between fractions of capital, and between capitalisms.

Keywords: Augusto Graziani, circuit theory of money, structural Keynesianism, Marx, Italian economy

JEL codes: B59, E58

Among all the many economists involved in the development of an alternative approach to neoclassical economics, both in terms of theory and policy, the name of Augusto Graziani stands out among all others. Born in Naples in 1933 and now aged 80, Graziani has had a long and distinctive career.

Although perhaps not in a fully conscious way in the beginning, Graziani's writings on theory and policy show a departure from the canons of orthodoxy.

Trained in Naples, he graduated in 1955 with Giuseppe Di Nardi. Graziani then travelled abroad to continue his schooling. Soon after, he did postdoctoral studies at the London School of Economics where he met Lionel Robbins, and then went to the United States, to Harvard University, where he was exposed to the influence of Wassili Leontief and Paul Rosenstein-Rodan. His long collaboration with Manlio Rossi-Doria at the Centro di Specializzazione di Portici must also be mentioned.

Graziani's works can be described as both theoretical and applied. From the very beginning, his work showed a distinctive style and approach. To wit, consider his 1965 book, Equilibrio Generale ed Equilibrio Macroeconomico (General Equilibrium and Macroeconomic Equilibrium). Readers may recall that these were the years when 
neoclassical theory was being assailed on theoretical grounds for its internal inconsistencies with respect to the theory of capital and distribution. As such, the fallacy according to which the distributive shares of the various factors of production were paid according to their marginal contribution to production was exposed. This was a crucial blow, because without respect for these conditions, the system's natural equilibrium collapses.

Graziani, however, always preferred to take a somewhat different path. In fact, in his 1965 book, Graziani defends the Walrasian (instantaneous) general equilibrium system because it was considered a better representation of how the market works, and a superior explanation to the (then in vogue) 'proportional' macro-models of growth. Rather, Graziani challenges the basic assumptions of orthodox theory by rejecting the initial definition of the economic and social world as being populated by identical individuals, where consumers are sovereign, technology is exogenous and money is neutral. Large social or 'macro' groups matter, and corporate power is essential in a world of permanent imbalances and conflicts.

These fundamental ideas are at the core of his approach, even in works related to the study of Italian economic development. For instance, in 1969, Graziani published Lo Sviluppo di una Economia Aperta (The Development of an Open Economy), in which he argues that the competitiveness of an economy depends neither on factor endowments nor on comparative advantages. It is, rather, the choice of entering the world market that imposes the adoption of the necessary technologies, which in turn determines the dynamics of productivity and the labour force to employ, where workers can enjoy relatively high wages. The remaining workforce will have to find employment in sectors that produce goods and services that are not traded externally, in a circle of low productivity and low wages. The development and imbalances of the Italian economy are seen, in short, as inseparable aspects of a unique mechanism. This 'dualism' is exacerbated by an export-led growth strategy, which is a bearer of consequences both positive and negative.

The 1970s witnessed a radicalization of Graziani's views. The author did not hesitate to confront the divide between orthodoxy and heterodoxy, and shifted the focus away from the usual ground of the theory of value - 'subjectivism', of the Walrasian or Marshallian kind, versus 'objectivism', following Ricardo - to a less explored topic: the essentiality of the role of money in a capitalist economy. This went well beyond the particular case of the 'crisis' defended by Keynesians with their emphasis on money as a store of value. From this radicalization, in the mid-to-late 1970s Graziani published a totally renewed version of his influential two-volume textbook, Teoria Economica (Economic Theory), originally published in 1967. Volume I dealt with prices and distribution, while volume II covered macroeconomics (by 2000, the books were in their 5th edition; the radical revisions of the books appeared in 1976 for the macro book, and in 1979 for the price and distribution book), both of which traced the uneasy coexistence of the 'compatibilist' and 'conflictualist' visions, with a special focus on the latter for the monetary heterodox strand of thought.

Graziani's efforts have since aimed at rebuilding on solid foundations the line of inquiry that sees capitalism as a 'monetary economy of production'. Keynes's famous depiction of such an economy now assumes a meaningful place for the first time. Along these lines, Graziani's most celebrated achievement is his wonderful 2003 book, The Monetary Theory of Production, an earlier version of which was published in Italian in 1994. While very Keynesian, there is a definite Marxian influence; in fact, in 1983 Graziani dedicated a couple of papers to Marx where he attempted to restore the macro-monetary nature of his labour theory of value, reducing to a secondary 
issue the notorious problem of the transformation of values into prices of production (the two articles have been translated in the International Journal of Political Economy in a special issue I edited in 1997: see Graziani 1997a; 1997b). However, authors such as Schumpeter and Keynes, and before them Wicksell, were all influences on Graziani's work. This theoretical lineage, according to Graziani, stands in opposition to neoclassical theory in two important ways. First, it focuses on large macro-social groups (the banking system, the firm sector, wage earners); second, and amounting to largely the same argument, it places the emphasis on power and conflict.

The key element here lies in the availability of monetary means of payment, and the notion that different classes have different degrees of accessibility to it. In the basic model, a closed economy without the state, money enters the economy as purchasing power, because banks finance the entrepreneurial class, which allows companies to set in motion the production of commodities and promote innovations. From this analysis, Graziani reaches a number of original conclusions. First, the privileged access to (credit) money becomes critical to the allocation of workers between sectors and the distribution of income between classes: the choices made by bankers and entrepreneurs determine in fact the amount of goods made available to workers, as in Keynes's Treatise on Money. Mere increases in monetary income can therefore be utterly unable to alter the division of real wealth, if the real choices of banks and businesses do not change.

Second, workers' conflict is an important factor in this process. But not so much the workers' conflict that takes place immediately on the determination of nominal wage; rather, the conflict that arises within the production processes, as well as, broadly speaking, in the political arena. Furthermore, the ownership by families of firms through equity, or the indebtedness of private firms towards households, does not lead to actual control over real decisions. The decisive command on resources depends on two crucial elements: first, on the availability of bank credit, which may limit production and investment; and second, on the interest rate on bank loans, which truly constitutes a subtraction from gross profit, as it is not true of interest on securities issued by the firm sector and sold on the financial markets.

Moreover, for Graziani, the recent phenomenon of the financing of household indebted consumption, which characterized the US economy in the years of the new economy (but which has spread to the European economies), is interpreted as an indirect financing of business, and not at all as a denial of his theoretical framework. As he writes in his Federico Caffè Lectures (2003), depicting in a few lines the features of the last phase of Neoliberalism:

More often than not, contemporary literature insists on the fact that credit granted to households equals or even exceeds credit granted to firms. It is, however, highly debatable whether credit granted to households is really given to consumers or is in fact indirectly granted to firms, by allowing consumers to buy finished products (Graziani 2003, p. 21).

This theoretical approach shapes Graziani's point of view when studying the Italian economy. For instance, it is at the heart of the introductions he wrote for his reader L'Economia Italian (for the publisher il Mulino from Bologna), in three editions (1972; 1979; 1989), which became bigger and bigger over time and culminated in a book, Lo Sviluppo dell'Economia Italiana: Dalla Ricostruzione alla Moneta Europea (The Development of the Italian Economy: From Reconstruction to the Euro) (Graziani 1998 [2000]).

The originality of Graziani's thinking continued to develop. In the 1970s, for instance, Graziani clarified how behind the apparent 'stalemate' between classes, there is a significant restructuring process, inside and outside the big factories, which erodes the 
strengths of the workers' conflict. As a result, a redistribution of surplus value in favour of the banks follows. All these processes are supported by economic policies that at first combine inflation with differential devaluation (1973-1979), and then use the 1975 agreement on the 'scala mobile' (the Italian system of wage indexation, generalized and empowered at the end of 1975) to generate a massive fiscal drag. This results not only in an aggressive defence of profits, but also in the expansion of (balanced budget) public spending favouring the restructuring of capitalist firms.

In the 1980s, Italy's entry into the EMS (European Monetary System), combined with the exhaustion of the experience of public enterprises, and the attack on the 'scala mobile' are seen by Graziani as stages of a plan by the ruling class that produces a subordinate modernization of Italy at the cost of waiving technological autonomy. In this context, the explosion of public deficits during that decade (that Marcello De Cecco labelled 'criminal Keynesianism') is once again interpreted by Graziani in a very radical way: it promotes the financial reorganization of enterprises by providing them with money 'for free', so to speak, making firms as a whole increasingly independent from the banking sector. Moreover, in the years 1987-1991 the high interest rates that pushed up the rising public debt were maintained by the Central Bank to induce capital movements compensatory to the growing trade balance deficit, to keep a high exchange rate, and to force firm restructuring in a context of wage repression and a compression of public social spending.

The failure of public enterprises, in this view, was not due to technical or categorical limitations. Things were very different: the real objectives of economic policy were divergent from those proclaimed, political support was lacking, and the social base that could support it was more and more fragmented and weakened.

Graziani has been a consistent and profound critic of the way the path to monetary unification has been pursued in Europe. He has highlighted better than most writers the neo-mercantilist drive imposed on the European economy by the constant will of Germany to bind together a system of fixed nominal exchange rates in Europe with a competitive deflation and a real devaluation of its commodities. These features of the EMS, after the parenthesis of the 1990s, reappeared emboldened in the experience of the euro, and nowadays risk giving way to its dissolution in the medium-to-long term. But Graziani also knows very well the limits of the strategy of competitive devaluations followed by countries like Italy. The return to a policy of devaluations would affect unequally a country like Italy, which has profound geographical divergences, where the exporting industries are heavily concentrated in certain areas and absent in others, and where the big industries (private and public) have been dismantled. Exiting the euro may deepen austerity, rather than reverse it (the rhetoric about money sovereignty notwithstanding). The pressure on countries like Italy comes from the fact that it is squeezed between the competition of the economies characterized by intense technical change and innovation, on one side, and the competition of the developing economies which may exploit the lowering of wages and the worsening of labour conditions, on the other. The only true way out remains, once more, structural policies enhancing technological autonomy driven by the State.

It may be interesting to ask what legacy Graziani leaves us: in particular, what do his most coherent thoughts suggest today? Now that the once-fashionable subject of the end of the interventionist period (1980s and 1990s) has been disproved in practice over recent years, we see many asking for a too-easy return to a too-generic 'Keynesianism', both from the right and the left, perhaps sometimes even invoking a 'post-Keynesian' and 'circuitist' descendance.

Graziani's confidence in the effectiveness of monetary policy has always been rather limited, to my understanding. Deficit spending, monetarily financed, is instead 
certainly considered by him as a means to sustain profits. All this, mind you, can have a positive effect on employment, but without any mechanism, everything depends on the real autonomous choices by firms and banks. Nor can we assume an inevitable positive effect of 'expansionary' policies on workers' share of the distribution of income. To Graziani, the real choices of businesses are mostly independent of the dynamics of monetary incomes distributed to households through wages, or through forms of basic income, or through taxation and transfer policies.

If one wants to shift the distribution of income in favour of labour, and at the same time affect not only the level of employment but also its allocation and the quality of output, we need to do something else, more structural. It is no coincidence that Graziani has always been in favour of an active industrial policy by the State. And it is clear that his prescription for economic policy is not limited to invoking a pure and simple increase in public spending. For Graziani, Keynes's paradoxical advice in the middle of the Great Depression is justified: better to dig holes to fill them again, rather than leaving workers unemployed. Nevertheless, since the shortcomings of the private system of production are profound and since collective needs are seriously unsatisfied, it would be foolish, he writes, not to carefully evaluate every expense; and it would be a waste not to generate a socially useful and productive composition of output. If it wants to ensure to its citizens the real availability of specific goods and services, the government cannot operate solely through subsidies and remission of taxes, or just settle for a generic rise in effective demand. Rather, it must directly provide those goods and services in real terms - that is, it has to do it directly 'in kind', and expand firms' outlets in a targeted way.

Direct State intervention is essential for Graziani also on the matter of structural investments. When you need to radically change the conditions of production, or to introduce new and unknown technologies, or to open new horizons for long-term investors, competition and private initiative are not enough. Public decision-making is necessary. The efficiency of the production system and of the private market cannot but depend on public action. We are confronted here with an idea of State intervention where demand policies are not separated from supply-side policies, and are indeed embodied in a structural design to redefine the composition of production that is extremely attentive to the quality of labour - we have here a parallel with, although with some differences, Minsky's views on the socialization of the economy, with the proposals of the State as an employer of last resort. A similar argument can be found in the work of Alain Parguez.

In that sense, Graziani definitely is a structural Keynesian, heterodox even within the post-Keynesian environment. He has nothing to do, in any case, with New Keynesian Macroeconomics, which belongs to the new 'imperfectionist' component of mainstream economic theory, and which is today the conceptual basis of economic policies that may well be called 'social-liberal'.

The best representative of this other vision is undoubtedly Joseph Stiglitz, although the import to Italy of his ideas is often associated with economic policy conclusions much more moderate than those put forward recently by the Nobel Prize-winner himself. In this way of seeing things, hoping to overcome at once market failures and State failures, public intervention risks being reduced to a pale re-regulation of markets for goods, services and credit, which are nonetheless willingly liberalized, as well as to an industrial policy limited to changes in the structure of incentives and disincentives. To this it may be added the hope by some New Keynesians of a great fundamental orientation of the economy towards lesser inequality, something that risks becoming just a new instance of wishful thinking. Meanwhile, in Europe, the social-liberals accept the Maastricht criteria and the (non)Growth and (in)Stability Pact, or the absolute independence of the 
Central Bank: probably more for political reasons than for faith in the miraculous virtues of 'sound' finance. Of course, this is far from Neo-liberalism, which cares little for monopolistic positions or for burgeoning public deficits and public debts, only to wave them against the Welfare State and labour conditions. Indeed, the social-liberal alternative to Neo-liberalism seems to be socially benevolent, and marking its difference: it is compassionately against insecurity, that needs to be 'overcome', preferring flexibility to causalization, supporting workers with universal measures of income support and professional training.

Confronting these new theoretical approaches, it appears to me that Graziani's teaching is even more valuable than it was in past decades and leads to a degree of scepticism about most of this 'imperfectionism'. He reminds us that economic theory has to put at the heart of its discourse not the 'imperfections' of the market, but rather the 'normality' of power and conflict, not only between labour and capital, but also between fractions of capital, and between capitalisms. It must abandon the reference to an imaginary world of a barter economy 'disturbed' by money, or the delusion that money may be integrated into an economic model, which is non-monetary in its roots. Money must be at the foundations of the theoretical building as bank financing - that is, money as capital that activates the capitalist process. A vision in which, as has already been said, it is the access to money that determines the real structure of the production. Something that inevitably leads to a less watered down perception of the role of the State in the economy.

It is only by moving from here, perhaps going beyond Graziani, that it is possible to understand the new characteristics of contemporary capitalism. A capitalism supported by economic processes that have been proved unsustainable in the long run, and have been shaken by waves of structural change and of financial instability. And then we can try to take the challenge of building the 'economic theory of the future', which according to Schumpeter - for whom Graziani has great respect - consists of seeing economic evolution as a process generated within the economic system itself. The capitalist process is a constant internal transformation in historical time, which is shaped by the choices of entrepreneurs and financiers and, equally fundamentally, by social struggles and political intervention, not by consumer preferences.

\section{REFERENCES}

Graziani, A. (1965), Equilibrio Generale ed Equilibrio Macroeconomico, Naples: ESI.

Graziani, A. (1967 [2000]), Teoria Economica, Volume I: Prezzi e Distribuzione, Volume II: Macroeconomia, Naples: ESI, 5th edn 2000.

Graziani, A. (1969), Lo Sviluppo di una Economia Aperta, Naples: ESI.

Graziani, A. (1997a), 'The Marxist theory of money', International Journal of Political Economy, 27 (2), 26-50.

Graziani, A. (1997b), 'Let's rehabilitate the Theory of Value', International Journal of Political Economy, 27 (2), 21-25.

Graziani, A. (1998 [2000]), Lo Sviluppo dell'Economia Italiana: Dalla Ricostruzione alla Moneta Europea (The Development of the Italian Economy: From Reconstruction to the Euro), Torino: Bollati Boringhieri, updated edn 2000.

Graziani, A. (2003), The Monetary Theory of Production, Federico Caffè Lectures, Cambridge: Cambridge University Press. 